Jakša Krišto

University of Zagreb

Faculty of Economics and Business, Department of Finance, Croatia

e-mail: jkristo@efzg.hr

\author{
Alen Stojanović \\ University of Zagreb \\ Faculty of Economics and Business, Department of Finance, Croatia \\ e-mail: astojanovic@efzg.hr
}

Anita Pavković

University of Zagreb

Faculty of Economics and Business, Department of Finance, Croatia

e-mail: amusa@efzg.hr

\title{
IMPACT OF INSTITUTIONAL INVESTORS ON FINANCIAL MARKET STABILITY: LESSONS FROM FINANCIAL CRISIS
}

JEL classification: G12, G22, G23, G24, G28

\begin{abstract}
Institutional investors are seen as key investors on the financial market, crucial market makers, supporting market liquidity and activity, as well as important pillars of pension systems and for maintaining financial stability. Institutional investors, mostly pension funds and insurance companies, were considered to have a positive effect on financial stability because of their long-term investment strategy and funding. The recent financial crisis and its impact on financial market stability revealed serious systemic risk and interconnections between movements on financial markets and institutional investors' investment behaviour. Their investment policy, outflows and fire sales on the financial market had a great impact on market stability and deepening of the financial crisis. The purpose of this paper is to analyse the impact of institutional investors on financial market stability in the aftermath of financial crisis. The research will point out lessons learned from the financial crisis and point at key initiatives and necessary improvements in the field of institutional investors.
\end{abstract}

Keywords: institutional investors, financial market stability, financial crisis 


\section{INTRODUCTION}

Institutional investors represent specialised financial institutions which mobilize and manage savings of individual investors and institutions and invest on financial markets, depending on their risk profile, aims and investment horizon, all with the aim to increase investment value. Institutional investors are considered to be: pension funds, insurance companies, different types of investment funds and hedge funds. They perform significant functions for the economy and financial system as a whole, ranging from allocation of funds to being pension savings providers and operating as actors positively influencing financial market development. Institutional investors, being long-term investors, have a positive effect on the financial stability and can also foster long-term economic growth and development. However, the crisis revealed many flaws of the regulation and the market of institutional investors. Some of these are: herd behaviour of institutional investors, fire sales on the financial market, outflows, short-term approach to investment, business and regulation, regulatory oversight and hazardous behaviour of certain institutional investors.

The financial crisis encouraged numerous regulatory discussions and changes, whose aim was to reform financial system regulation and supervision in order to achieve financial stability, decrease systemic risk and avoid procyclicality. Microprudential regulation is in the process of reregulation from changes in regulatory requirements in the banking sector to ones in the sector of institutional investors and financial market. New initiatives emphasize the importance of institutional investors as long-term investors and economic growth as the final goal.

The article points out the influence of the financial crisis on institutional investors and financial market stability, together with the contribution of institutional investors to the development and transfer of the crisis. Key regulatory initiatives and other market initiatives are considered and suggested. The paper consists of six parts. After the introductory notes, the second part reports on the importance of institutional investors for the entire economy and financial system. The third part considers the theoretical framework and the connection between institutional investors and financial stability, primarily financial market stability. The fourth part problematizes the financial crisis and institutional investors' behaviour, while the fifth summarizes key conclusions and initiatives spurred by the financial crisis for the part of institutional investors and financial markets on the European Union level. The conclusion gives findings and further guidelines.

\section{IMPORTANCE OF INSTITUTIONAL INVESTORS}

Institutional investors represent specialised financial institutions which mobilize and manage savings of individual investors and institutions and invest on financial markets, depending on their risk profile, investment strategy, in order to increase investment value. The advantages of retail investing into institutional 
investors are seen in diversification of their investments, competent risk and assets and liabilities management, reduced information asymmetry and cost efficiency. Due to these advantages, institutional investors represent key investors and creators of liquidity on financial markets, especially prominent on capital markets (Davis and Steil, 2001, p.12). The importance of institutional investors for the financial system and economy in whole can be measured by indicators that put in ratio the assets of institutional investors and other economic or financial variables.

The significance of institutional investors in total financial institutions' assets differs among financial systems themselves. It is exactly the share of institutional investors that indicates the type of financial sector, being either bankbased or market-based. Numerous researches investigated the influence of financial structure on economic growth, among others Gerschenkron, 1962, Stiglitz, 1985, Allen and Gale, 1999, Levine, 2002, Demirgüç-Kunt and Levine 2004, Areatis et al. 2005 (Arestis et.al., 2005, p.1). The total financial system development is strongly related to economic growth, but there are no indicators pointing to the superiority of either the bank-based or the market-based financial system (Levine, 2002, p.398).

The total assets of institutional investors globally were around 85 trillion USD at the end of 2011 (OECD, 2012, p.4). Assets under management of pension funds accounted for 30 trillion USD, 24.5 of insurance companies, 23.5 of investment funds, 4.8 of sovereign wealth funds, 2.6 of private equity funds and 1.8 trillion USD of hedge funds (TheCityUK, 2012). Institutional investors represent the most important group of financial institutions in the USA. Their share in the total assets of all financial institutions was almost the half of total assets $(44 \%)$ in 2010. At the same time, the share of depository financial institutions was $27.1 \%$. In 2010 investment funds were the most important group of institutional investors with the $18.4 \%$ share; pension funds had a $17.1 \%$ share, while insurance companies had an $8.5 \%$ share in the total assets (FED, 2012).

In the bank based systems of Japan and the European Union, institutional investors are the second most important financial institution. In the Japanese financial system, banks are dominant with the share of $58 \%$ in total assets of financial institutions in 2010 and a share of institutional investors was $22 \%$. The most important group of institutional investors in this period were insurance companies with a $14.1 \%$ share, while pension and investment funds did not have such relevance with a $4.6 \%$ and $3.3 \%$ share (Bank of Japan, 2012). In Croatia, during the same period, institutional investors had a total share in the assets of the financial sector of $15.5 \%$ and as a share of GDP $24.3 \%$.

Investing in institutional investors is the most important form of savings of households, with the exception of Japan, where investing in cash and deposits was seen as more important. In the USA, investments in institutional investors made around $42.6 \%$ of total household assets, $31.7 \%$ in Japan and in the Euro area $38.3 \%$ on average and $24.1 \%$ in Croatia at the end of the 2nd quarter 2011. During the financial crisis assets of households, in part, were transferred into banking deposits as a safe and insured financial product. Different researches also 
confirm the fact that investing in institutional investors is a dominant form of household investments, see Davis and Steil, 2001, Guiso et al., 2002, Davis, 2003, BIS and Committee on the Global Financial System, 2007 and Nakagawa and Yasui, 2009 (BIS, 2007 and 2009). The key components within institutional investors represent investments in pension funds and insurance companies, as a form of long-term pension savings. The assets of institutional investors as a percentage of GDP for OECD countries were on average $162.6 \%$ for 2005 (Gonnard et.al, 2008, p.6).

\section{INSTITUTIONAL INVESTORS AND FINANCIAL STABILITY - THEORETICAL FRAMEWORK}

Financial stability is manifested through undisturbed functioning of all segments of the financial system in the process of allocation, risk assessment and management, payment system and resilience to sudden shocks. Financial stability is based on the trust of financial markets' participants and significantly depends on cyclic fluctuations in their behaviour and expectations. Since financial crises result in great economic and social costs, maintaining financial stability is seen as public good and as an important goal of economic policy (HNB, 2010, p.3).

Allen, W.A., Wood, G. define financial stability as a state of affairs in which episodes of instability are unlikely to occur, therefore the fear of financial insecurity does not influence economic decisions of households or companies. Financial instability is also defined as a state in which prudently managed households and companies encounter sudden financial difficulties and with unavailability of means of payment, leading to decreased aggregate consumption, which for authors is a proof of an existing financial crisis (Allen and Wood, 2006, p.152-172).

National committees for macroprudential regulation have been responsible for achieving and maintaining financial stability. Financial stability is closely related to financial system's efficiency as a key prerequisite for efficiency of the entire economy. Financial Soundness Indicators or other new indicators and measures of macroprudential regulation are used to measure financial stability.

A detailed analysis of the influence of institutional investors on financial stability should re-examine financial stability indicators and estimate to what extent they influence business activities of institutional investors. Financial stability indicators do not give great importance to institutional investors, more important; they put no emphasis on them. They are indirectly included in indicators of other financial institutions through ratio of other financial institutions' assets and financial system assets and with other financial institutions' assets and the GDP. Indirect significance of institutional investors is also seen in financial market liquidity indicators, where they play a crucial role as liquidity creators through market institutialization. Diversity of forms of institutional investors, long-term nature of their funds, long-term investment horizon and strategy, willingness to take risks are all characteristics which should 
have a stabilization effect on financial market conditions (Davis and Steil, 2001, p.255).

Institutional investors are also an important development and stability factor for capital markets. This fact anticipates the expected positive effects of institutional investors' investments on:

○ financial market liquidity,

- savings mobilization, efficient investment allocation together with development function of economy,

- contribution to market efficiency and reduction of transaction costs, improving arbitration processes,

- decrease of information asymmetry using information analysis and risk management, consequently reducing risk for individual investors (Levine, 1997, p.691).

Institutional investors also reduce exposure of the financial sector to bank intermediation, enhance financing and capital market development consequently resulting in more efficient corporate governance (Croce et al., 2011, p.5).

The growth of institutional investors' assets together with their share in total trade on financial markets resulted in financial market institutionalization, often perceived as a disadvantage. Financial market institutialization influences: fees for trading on the financial market, block trade, financial market organization, existence of settlement system and price volatility of securities. Theories differ on the influence of institutionalization on price volatility of securities. While some consider block trade spurs volatility, others say institutionalization increases liquidity and financial market efficiency. Davis, E.P. and Steil, B. analysed G7 countries and found that developed systems (measured by the share of total assets of financial sector in GDP) had more institutionalized financial markets. Greater institutionalization of the financial market results in higher share of stocks in total financial assets, while statistically significant connection of institutionalization level and financial market volatility has not been detected. In a stable environment on the financial market, institutional investors should ensure and accelerate achieving securities prices corresponding to their fundamental value. The above mentioned should be accomplished, since institutional investors have and process existing information, but also lower transaction cost (Davis and Steil, 2001, p.233). Development of institutional investors and financial market is closely connected. Markets with a higher indicator of institutional investors' assets as a share of GDP are characterised by a more developed and liquid financial market. This leads to the conclusion that institutional investors can have systematic significance for an efficient functioning of the financial market.

The influence of insurance companies on financial stability was analysed by the Geneva Association and the European insurance and reinsurance federation - Insurance Europe. Insurance Europe points to different roles of banks and insurers in the financial sector and to a different influence of the crisis on 
each of these institutions. The key differences in business activities of banks and insurers are: differences in conduct of business, sources of funds, balance sheet structure, liquidity risk, risk takeover and transparency, cross-sectoral interconnections, volatility, assets liability management and portfolio management. The differences between banking and insurance business are emphasized by the analysis of the Geneva Association, which points to a less significant influence of insurers and reinsurers on systemic risk and the entire financial stability.

However, the Geneva Association considers that activities like assets management and other financial services of insurers can be relevant for financial stability and have significant systemic risk. The key advantage of insurers is a different risk exposure, long-term constructional component of insurance policy and a long-term investment strategy, which acts as a stabilization factor for the financial system and market during periods of crisis (The Geneva Association and CEA, 2010). Similar conclusions can be made for other institutional investors, providers of financial products of voluntary pension savings, primarily for pension funds and some other types of investment funds.

\section{FINANCIAL CRISIS AND INSTITUTIONAL INVESTORS' BEHAVIOUR}

The Bank for International Settlements distinguishes five phases of crisis with different intensity. The first phase refers to the period from the beginning of June 2007 to mid March 2008, characterised by liquidity problems, bank losses and write-offs caused by non-performing subprime loans, which led to assets prices meltdown on the financial markets. The second phase, from mid March 2008 to mid September 2008, was characterised by growing problems with financing and solvency of certain business and investment banks and a threatening danger of bankruptcy for the mentioned institutions. Lehman Brothers investment bank went bankrupt on September 15th, 2008 and marked the beginning of the third and most intense phase of the crisis. The third phase lasted till end October 2008 and was characterised by the fall of stock exchange indexes and growth in costs of money, disinvestments, widespread illiquidity and lack of trust among financial intermediaries and other participants on the financial market. The trust was partially restored by the intervention of developed countries' governments together with the financial aid and liquidity funds. The fourth phase, from end October 2008 to mid March 2009, was marked by the adjustment of the financial market and its participants to the bleak surroundings and uncertainties concerning the effects of interventions on the financial markets of developed countries and the entire economy. During the fifth phase, which started mid March 2009, financial markets reflected signs of optimism, despite negative signals, macroeconomic environment and uncertainties connected to the end of economic and financial crisis (BIS, 2009, p.16-17). 
During the financial crisis, stock exchange indexes plunged worldwide between $40 \%$ and $70 \%$ in 2008 and gradually recovered after March 2009. Trading volume of shares plummeted on the world financial markets in 2008 and 2009 , except in the USA, where it grew in 2009. The market capitalization of companies listed on the stock exchange as a percentage of GDP on the world level in 2008 lost more than half of its value and was only $58.6 \%$, while in 2009 it recorded growth, to $80.8 \%$ of the GDP (WB Data Catalogue, 2012).

The trends and influence of the crisis on capital markets had a unique effect on the fall of stock exchange indexes and market capitalization in 2008, with a following recovery in 2009. Institutional investors have strongly contributed to these trends on the capital markets. Investment policy of these institutions and repositioning of portfolios during the crisis, accounting standards and "fair value", together with investors' behaviour, who, due to fear and mistrust, withdrew their funds, had a negative effect on the entire financial market and financial stability.

According to the OECD's analysis, pension funds' assets recorded investment losses, due to fall in asset value in 2008, in the amount of 3.5 trillion USD, while in 2009 they had a growth in assets of 1.5 trillion USD. Pension funds in the OECD countries had negative returns of $-21 \%$ in 2008, while in 2009 they recovered to a positive $6.6 \%$ (OECD, 2010, p.3).

Though the short-term impact is extremely negative, pension funds, as long-horizon institutional investors, should be evaluated over a longer period of time. In the time frame of the last 15 years, till October 2008, the average annual returns of pension funds were around $6.1 \%$ in the USA (OECD, 2008). The same conclusion is shown in chart 1 . 


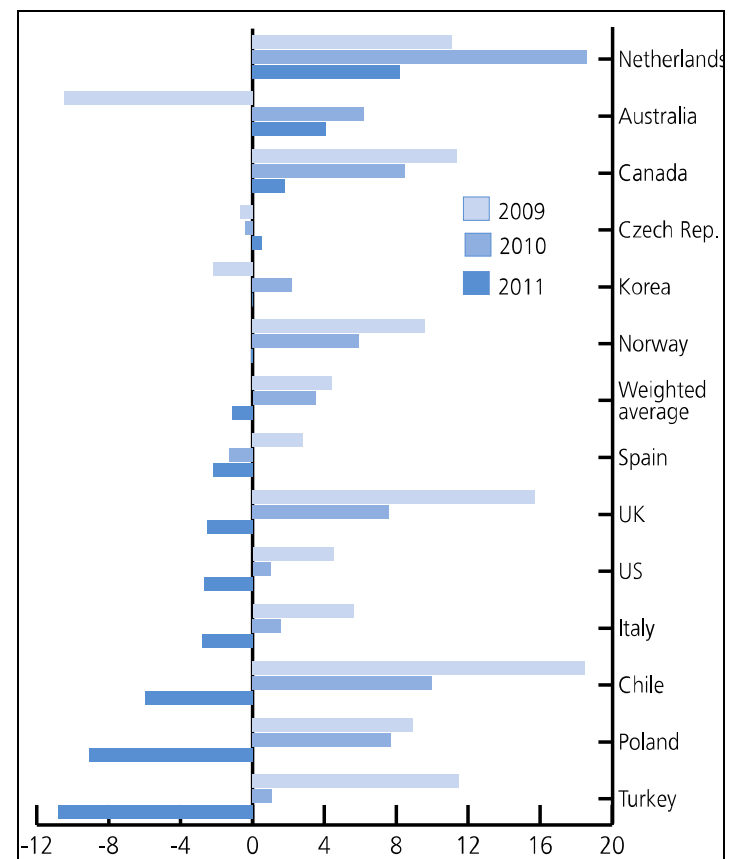

Chart 1: Real rates of return of pension funds in some OECD countries in percentage rates

Source: TheCityUK, 2013

The crisis influence on insurance and reinsurance business activities was strongly reflected in: the fall of premium income, investments and change in investment portfolio, the fall in investment profitability and total profitability, significant losses on specific insurance lines, exposure to "toxic" financial assets and non-traditional activities (OECD, 2010 and Liedtke et al., 2010).

The research and analysis of the Geneva Association and the Insurance Europe emphasize that insurance sector was not the origin of the crisis nor did it contribute to it with its business activities, consequently resulting in a weaker impact of the crisis (Liedtke et al., 2010). The insurance sector was not the key recipient of the financial support either. During the crisis, government and central banks of the G20 countries have, directly and indirectly, helped the financial sector with 10 trillion USD, out of which only 10 billion USD went to the insurance sector (CEA, 2010, p.3). When taking into consideration the fall in premium income, investment losses and reduced profitability, financial crisis did have a strong effect on the insurance sector, as well as the rest of the financial sector. Changes in investment policy and new regulations of these institutions have further deepened the crisis on the financial market. Contractional component of life insurance policy and its long-term saving have prevented more significant outflows from this sector. 
Investment funds were the most exposed to the crisis influence due to the nature of their business activities. The investment funds' assets recorded a worldwide downfall of nearly $-30 \%$ in the period from end 2007 till end 2008. At the end of 2007, this fall amounted to 26.1 trillion USD and 19 trillion USD by end 2008. Their assets again grew at end 2009 and beginning 2010, recording 23 trillion USD at the end of the first quarter (TheCityUK, 2010, p.3).

The structure of investment funds according to investment strategy has changed significantly. Stock and mixed types of investment funds have lost importance and their share, while money market funds in the period of crisis grew. In 2008, investment funds recorded significant outflows causing portfolio management difficulties, but also having a negative effect on the financial market as a whole (EFAMA, 2011, p.3-4). The total net assets of the UCITS investment funds in the EU were reduced by $26.4 \%$ in 2008 and net capital outflows were 356 billion Euro, while only money market funds had net capital inflow (EFAMA, 2011). These trends on the example of investment funds in the EU are shown in chart 2.

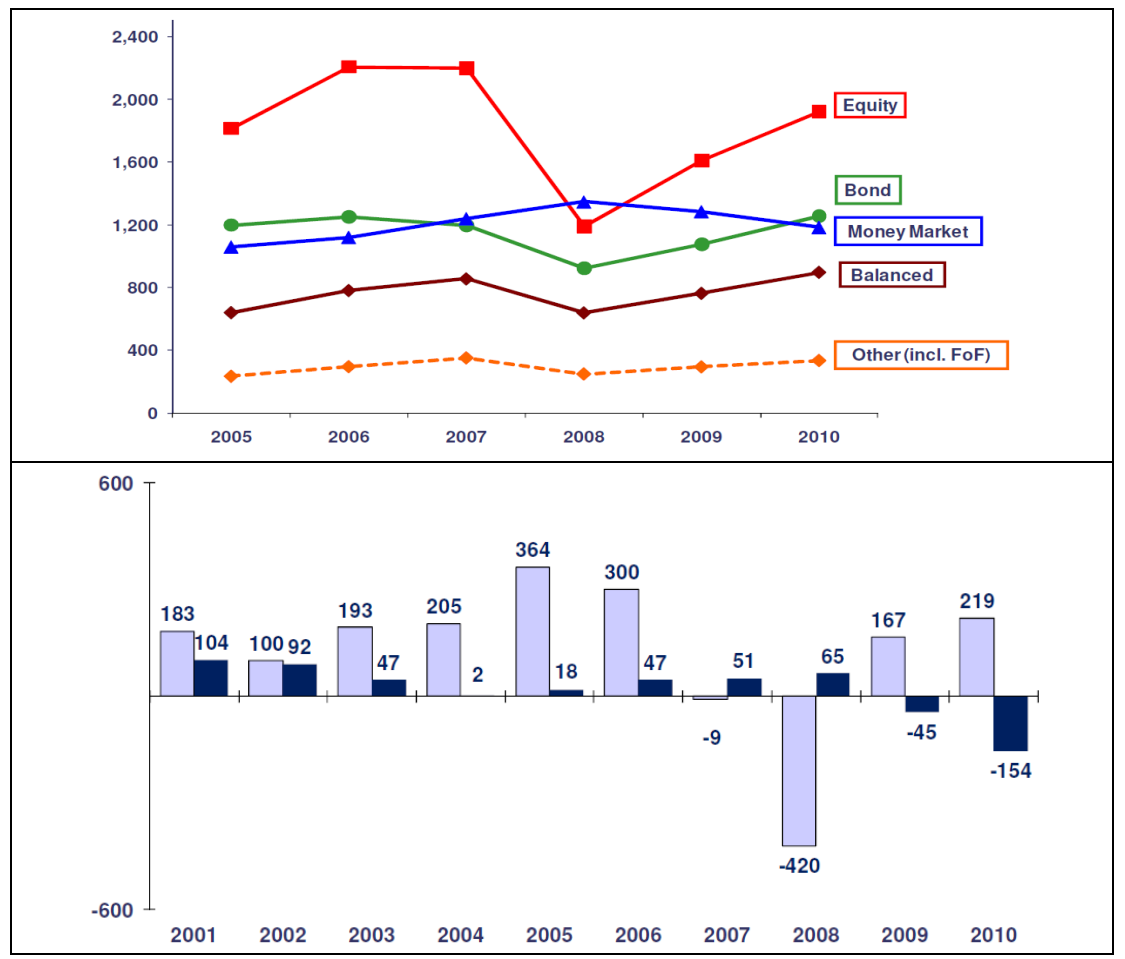

Chart 2: Assets and net outflows from investment funds in the European Union, in billion Euros

Source: EFAMA, 2011, p.3-4. 
In 2009, the number of investment funds in liquidation process in the USA was higher than the number of newly established funds, being also one of the consequences of the crisis. The number of newly established funds was 457 , 824 had exited the market, 488 was going through the process of fund liquidation, while 336 were merging with other funds (ICI, 2010, p.15).

The financial crisis has revealed shortcomings and the true character of business conduct, regulation and institutional investors' behaviour. The crisis demonstrated that institutional investors, as well as the rest of the financial sector acted procyclically (Croce et al., 2011, p5). The key characteristics of this kind of approach were: short-term approach to business and investments, herd behaviour, disinvesting on capital markets, inadequate inclusion and prediction of market changes. Additional stimulus to the crisis came from fire sales and outflows from investment funds and other institutional investors, to a smaller extent. The responsibility for this kind of consumer behaviour can be found in an inadequate level of investment protection of institutional investors, lower risk tolerance and still insufficient financial literacy.

\section{LESSONS AND INITIATIVES AFTER THE FINANCIAL CRISIS}

The regulatory framework and the supervisory architecture of the EU financial system were altered focusing on macroprudential regulation and improvement of microprudential regulation and supervision. Three new European agencies were established in the beginning of 2011 - European Banking Authority, European Insurance and Occupational Pensions Authority, European Securities and Markets Authority and European Systemic Risk Board. The new supervisory architecture wanted to restore confidence in the financial system and supervise financial institutions more efficiently. Special emphasis was put on achieving and maintaining financial stability as the fundamental goal of macroprudential regulation.

As concerns institutional investors, macroprudential regulation should ensure stability of, primarily, capital markets, point to the danger of creating "bubbles" and establish warning signals for financial crisis, but also act as a manager at the onset of a crisis. The framework of macroprudential regulation, instruments and indicators are still in the beginning phase (Stojanovic and Kristo, 2012).

On the level of microprudential regulation the process of forming new Solvency II regulations is still an ongoing process in the insurance sector. It started back in 2002, with the first phase ending in 2009, with the adoption of the Solvency II directive 2009/138/EZ. Current disputes are connected with the Omnibus II directive which should complement Solvency II directive for the authorities of the European Insurance and Occupational Pensions Authority. In order to implement full Solvency II regulation, Omnibus II and level two and level three measures, together with supervisory guidelines and technical standards, have to be adopted. Solvency II introduces risk based regulation into 
the insurance sector and significantly tightens capital adequacy calculations, risk management and consumer protection. Solvency II should come into force in the beginning of 2014, probably in a reduced form (HUO, 2013, p.27).

European Insurance and Occupational Pensions Authority sent its final proposal on the new regulation for occupational pension funds at the beginning of 2012. When revising the directive on occupational pension funds, the European Commission has expressed intention to improve the single market of financial services for occupational pension funds, to ensure their business activities among member states, develop risk based regulation of these institutions and ensure identical business conditions among financial institutions (EIOPA, 2012).

Regulatory provisions of the UCITS investment funds are in the process of reshaping; therefore the proposal for the new UCITS V directive was issued by the European Commission in 2012. The goal of the new Directive is to improve safety for investment funds' investors and improve integrity of the financial market (ECB, 2012). There is a strong concern about the short-term approach and the problem of herd-behaviour concerning Solvency II regulation (Rohde, 2011, p.4), but also about the amendments to occupational pension funds regulation.

The regulation of Credit rating agencies and financial market infrastructure is also being reshaped. The regulation of Credit rating agencies needs to be improved in order to increase their reputation and market competition, their role in regulatory requirements of other financial institutions, to define a model of payment of their services and reform their conduct of business (Pavkovic and Vedris, 2011, p.22-24). Regulatory reform of OTC derivatives market are based on more efficient rules on trading and issuing derivatives, market infrastructure, settlements and standardisation, managing systemic risk and regulatory arbitrage (Pavkovic, 2013, p.90). The securitization process and securitization market needs new rules and enhanced market discipline as well. Liquidity risk was also underestimated, including problems in financial institutions' risk management and in the systemic oversight (Kordic and Pavkovic, 2011).

Achieving economic growth once again and channelling institutional investors' assets into long-term investments is one of the essential strategic initiatives of both the European Commission and the OECD. The European Commission issued the Green Paper on the long-term financing of the European economy (EC, 2013) in March 2013 and stimulated the debate and creation of the new strategic framework. At the same time, the OECD and the G20 countries started a project called Institutional investors and long-term investments in May 2012.

To improve and encourage institutional investors to long-term investments, it is necessary to reform the regulatory framework of institutional investors, encourage more active approach to investments and more active shareholding, ensure state support for investing into long-term projects, assure adequate education and consumer protection (Croce et.al., 2011, p5). Investments of institutional investors into long-term development projects using capital market would ensure additional stability for the financial market, since long-term 
approach to investments would have a stabilizing effect in times of crisis and instabilities.

Improvements in incentive framework of institutional investors' business conduct refer to enhanced consumer protection and financial education, forming additional sector guarantee mechanisms or guarantee schemes, ensuring liquidity and stabile infrastructure of the financial market, forming an incentive framework by the government as regards investment climate, debt policy and tax incentives for voluntary pension savings. An important issue is also a more significant involvement of institutional investors in corporate governance and improvement of corporate governance practices (OECD, 2011).

In Croatia, these incentives are still not being recognised. A body responsible for macroprudential regulation has not yet been established and that is the first step towards building a framework of macroprudential regulation in Croatia. As for microprudential regulation Croatia will comply with new regulatory requirements in the European Union and being a member state will be in a position to contribute to creating new regulation. The long-term benefits of the investment policy of institutional investors have to be emphasised especially due to the specificities of the mandatory second pillar pension funds in Croatia. Other incentives from consumer protection, financial education and tax incentives to pension savings are at an initial phase.

\section{CONCLUSION}

Institutional investors are a significant segment of the financial sector and the economy as a whole. The recent financial crisis has strongly influenced their profitability, investment policy and pointed to the herd-behaviour. Investors holding portfolios in institutional investors have also reacted by outflows and disinvestments. This significantly influenced the stability of the financial market, resulting in shortage of liquidity during the crisis, fire sales and inability of the financial market to fulfil its basic functions of transferring and allocating financial means. However, the commitment to redefining bank regulation was dominant shortly after the crisis, as well as forming macroprudential regulation, mostly bank oriented. Recently, the importance of institutional investors has been emphasized together with their mediation in channelling long-term investments with the aim to achieve economic growth. Macroprudential regulatory changes have been intensified for all types of institutional investors, as well as measures to improve market environment, financial education and consumer protection. As regards macroprudential regulation and the importance of institutional investors further steps have to be made in order to develop analytical framework testing the influence of institutional investors on maintaining financial stability. The paper discusses key areas essential for improving the sector of institutional investors. Some of these initiatives have been implemented, while others still await their implementation on the EU level. Therefore conclusions and recommendations in this paper can be useful as guidelines for creators of economic policies and financial sector regulation in Croatia. 


\section{REFERENCES}

Allen, W.A., Wood, G. (2006). Defining and achieving financial stability. Journal of financial stability, 2, Elsevier.

Arestis, P. et_al. (2005). Financial Structure And Economic Growth. University of Cambridge, Cepp Working Paper No. 06/05

BIS and CGFS. (2007). Institutional Investors, global savings and asset allocation. BIS CGFS Papers No27

BIS. (2009). Household debt: implications for monetary policy and financial stability. BIS Papers No 46

BIS. (2009). $79^{\text {th }}$ Annual Report, 1 April 2008 - 31 March 2009.

banks,

CEA. (2010). Insurance: a unique sector, why insurers differ from http://www insuranceeurope eu/uploads/Modules/Publications/1277383780_ceareport-insurance-a-unique-sector.pdf

Croce, R.D. et.al. (2011). Promoting Long-Term Investment by Institutional Investors: Selected Issues and Policies. OECD Journal: Financial Market Trends, Vol. 2011 - Issue 1

Davis, P.E., Steil, B. (2001). Institutional Investors, The MIT Press.

EC. (2013). Green Paper Long-term financing of the European economy, accessible at: http://eurlex.europa.eu/LexUriServ/LexUriServ.do?uri=CELEX:52013DC0150:EN:NOT

ECB. (2012). Financial Stability Review, accessible at: http://www.ecb.int/pub/pdf/other/financialstabilityreview201212en.pdf?ccb79c12 91d6684259fd4600b2745ba4

EFAMA. (2011). Trends in the European Investment Fund Industry in the Fourth Quarter of 2010 and Results for the Full Year 2010, accessible at: http://www.efama.org/Publications/Statistics/Quarterly/Quarterly\%20Statistical\% 20Reports/Quarterly\%20Statistical\%20Report\%20Q4\%202011.pdf

EIOPA. (2012). EIOPA's Advice to the European Commission on the review of the IORP Directive., accessible at: https://eiopa.europa.eu/fileadmin/tx_dam/files/consultations/consultationpapers/C P06-11/EIOPA-BOS-12-

015_EIOPA_s_Advice_to_the_European_Commission_on_the_review_of_the_I ORP_Directive.pdf 
FED. (2012). Flow of Funds Accounts of the United States Flows and Outstandings, accessible

http://www.federalreserve.gov/releases/z1/20130307/z1.pdf

HNB. (2010). Financijska stabilnost, br. 5, Godina 3

Hrvatski ured za osiguranje. (2013). Bilten br. 8.

ICI. (2010). Investment Company Fact Book 2010.

Kordić, G., Pavković, A. (2011). Securitization market crisis and monetary policy responses. International scientific conference - MSKE 2011, Universidade Lusiada de Vila Nova de Famalicao

Levine, R. (2002). Bank-based or Market-based Financial Systems: Which is Better? Journal of Financial Intermediation, 11(4), Elsevier

Levine, R. (1997). Financial Development and Economic Growth: Views and Agenda. Journal of Economic Literature, Vol. XXXV

Liedtke, P.M. et.al. (2010). Anatomy of the credit crisis. The Geneva Reports Risk and Insurance Research, The Geneva Association

OECD. (2013). Draft high-level principles of long-term investment finaancing by institutional investors, accessible at: http://www.oecd.org/daf/fin/HL-Principles-LTI-Public-Consultation-May2013.pdf

OECD. Pension Markets in Focus, accessible at: http://www.oecd.org/finance/private-pensions/pensionmarketsinfocus.htm

OECD. (2011). The Role of Institutional Investors in Promoting Good Corporate Governance, accessible at: http://www.oecd.org/corporate/ca/corporategovernanceprinciples/49081553.pdf

Pavković, A. (2013). Regulatorna reforma infrastrukture izvedenica. Računovodstvo i financije, No. III

Pavković, A., Vedriš, D. (2011). Redefiniranje uloge agencija za kreditni rejting u suvremenom financijskom sustavu. Ekonomska misao i praksa, Sveučilište u Dubrovniku. godina XX, No 1

Rohde, L. (2011). Lessons from the Last Financial Crisis and the Future Role of Institutional Investors. OECD Journal: Financial Market Trends, Vol. 2011 - Issue 1 
Stojanović, A., Krišto, J. (2012). Designing macroprudential regulation: policy, tools and early warning signals. Proceedings 6 international conference, Faculty of Economics and Business Zagreb

The Geneva Association. (2010). Key financial stability issues in Insurance, accessible

https://www.genevaassociation.org/media/99181/GA2010-

Key_Financial_Stability_Issues_in_Insurance.pdf

The Geneva Association. (2010). Systemic Risk in Insurance - An analysis of insurance and financial stability., accessible at: https://www.genevaassociation.org

The World Bank Data Catalogue. (2012). http://data.worldbank.org/topic/financial-sector

TheCityUK. (2012). Fund Management 2010 and 2012., accessible at: http://www.thecityuk.com/research/our-work/reports-list/?start=0 